\title{
Instructional Leadership Practices Among Headmasters and The Correlation with Primary Schools' Achievement in Sabah, Malaysia
}

\author{
Fazal Mohamed Mohamed Sultan ${ }^{1}$, Gunasegaran Karuppannan ${ }^{2} \&$ Justin Rumpod $^{3}$ \\ ${ }^{1}$ Faculty Science Social and Humanities, Universiti Kebangsaan Malaysia, Malaysia \\ ${ }^{2}$ Centre for Graduate Studies, University Selangor, Malaysia \\ 3 Kolompong Secondary School, Kota Kinabalu, Sabah, Malaysia \\ Correspondence: Fazal Mohamed Mohamed Sultan, Faculty Science Social and Humanities, Universiti \\ Kebangsaan Malaysia, 43600 Bangi, Selangor, Malaysia.
}

Received: January 3, 2022

Accepted: January 26, 2022

Online Published: January 27, 2022

doi: 10.5539/elt.v15n2p50

URL: https://doi.org/10.5539/elt.v15n2p50

\begin{abstract}
This study aims to identify the correlation between the instructional leadership practices by the headmasters with the level of performance and achievement of schools in Malaysia. A total of 141 respondents comprised of senior assistants of primary schools were examined. Respondents' perceptions of instructional leadership practices by the headmasters were gained using a set of questionnaire that was modified from the Principal Instructional Management Rating Scale (PIMRS). Descriptive statistical analysis was used to obtain the mean score, percentage, and standard deviation of the instructional practices. At the same time, ANOVA test was applied to obtain the perceptions from demographic factors and Pearson Correlation to measure the relationship between the instructional leadership and the schools' performance that is based on band measurement. The findings show that the level of instructional leadership practice is high, with a mean of 4.24. Band 1, 2, 3 and 4 schools each have $\min$ of $4.374 .23,4.23$ and 4.05 respectively. Pearson correlation analysis shows that there is a weak negative correlation between the headmasters' instructional leadership practices level and the performance of the schools $(r=-0.210)$. Thus, findings conclude that the level of instructional leadership practices among headmasters in primary schools is high and has a weak negative relationship in-term of schools' achievement.
\end{abstract}

Keywords: instructional leadership, achievement, questionnaire, relationship

\section{Introduction}

High performing and committed school leaders should be able to bring changes, improve the performance of the schools, and students' achievement. In the Malaysian Education Development Plan (PPPM) 2013-2025, the Ministry of Education Malaysia (MoE) has committed to place high quality headmasters and a team of school leaders to drive schools' excellence. Thus, among the main focus is to improve the quality performance of school leadership by improving the training and selection methods of school leaders. Through this transformation, MoE is highly confident that headmasters are not only capable of serving as an effective and outstanding head administrator, guiding the teachers, being agent of change in their schools and communities, but also as an effective instructional leader. Therefore, as the leader of the school, the headmaster needs to play a role as a motivator, mentor, and teacher supervisor to improve and maintain the quality of teaching in the school (Rutil \& Gunasegaran, 2021).

According to Hallinger (2011), instructional leadership has a positive relationship and contributes significantly to the quality of teacher teaching. In fact, the study of Sazali, Rusmini, Abang Hut and Zamri (2007) shows that there is a relationship between instructional leadership practices and students' academic achievement. Therefore, the instructional leadership by headmasters should be given emphasis in schools. Sufean (2014) explained that instructional leadership refers to leadership that focuses on academic management matters, improvement of teaching and learning process in the classroom is the main function of headmasters while other areas of leadership include maintaining their school's excellence. School leaders who exhibit low performance in their duties and roles as instructional leaders are considered as ineffective school leaders and they are also categorised as ineffective (Mohd. Yusoff \& Sufean, 2013). Mohd. Suhaimi (2004) emphasises that the role and responsibilities of a headmaster is very broad, namely as the leader in the school, administrator, manager and 
carry out teaching duties at least five hours a week. In this study, the researcher used Hallinger and Murphy's (1985) Instructional Leadership Model as the basis of the study. According to the model, instructional leadership is divided into three main dimensions and has 10 leadership functions. The dimensions are defining the goals of schools, managing instructional programs, and promoting a learning climate. The model discusses instructional leadership comprehensively and has been widely adopted in developed countries such as the United States of America, Britain, Australia, and Finland. This demonstrates its popularity and suitability as a research model in the field of instructional leadership.

\subsection{Problem Statement}

The leadership of the headmaster is a major factor in determining the progress of a school (James \& Balasandran, 2011). Instructional leadership has been identified to have a positive relationship in-term of students' academic performance (Hallinger, 2011). Records show that Tuaran District in Sabah, one of the states in Malaysia, faced a decline in the achievement in the Standard Six public examination - Primary School Assessment Test (UPSR) in year 2014, 2015 and 2016. The Malaysian Plan of Education Development (2013-2025) has categorized school performance based on band 1 to band 4, in which band 1 is the best performance. In 2015, the decline in performance is obvious with the existence of four categories of bands, namely $20.55 \%$ in Band $1,26.03 \%$ (Band 2), $41.10 \%$ (Band 3) and $12.33 \%$ (Band 4). Analysis of UPSR results in the following year showed a decrease District Average Grade (GPA) of 2.57 to 3.04 with the number of excellent schools with Grade Point Average (GPS) 1.0 to 1.99 were only $6.76 \%$. Schools that earned GPS 2.0 to 2.99 were $58.11 \%$, and $35.13 \%(3.1-3.99)$. Apart from that, the performance of schools by location significantly raises various questions. For example, most of the schools in Band 1 are in Nabalu Zone, Kiulu Zone and Tamparuli Zone. Meanwhile, Band 4 schools are mostly in the Sulaman and Mengkabong Zones. Therefore, the researcher strongly felt that a study needs to be conducted to examine what are the factors that caused the problem. If the situation or problem is persisting, it not only shows that the schools' leadership are ineffective, but it is also feared that it will jeopardise the school's performance in the long run. Therefore, a leadership model needs to be studied as an alternative effort for school performance improvement. Accordingly, this study was conducted based on the following objectives:

i. To determine the level of instructional leadership practices among primary school headmasters in Tuaran District.

ii. To identify the level of instructional leadership practices among headmasters based on school bands in Tuaran District.

iii. To identify differences in the level of instructional leadership of headmasters in Tuaran District based on demographic factors.

iv. To analyze the relationship between the instructional leadership practices of principals with the achievement of school bands in Tuaran District.

\subsection{Significance of the Study}

The main challenge faced by the $\mathrm{MoE}$ is to improve the quality of education. For example, although students' performance in national examinations such as UPSR and SPM, examination for Form Five students, is increasing, the performance gap between urban and rural areas is still significant and the results of the Program for International Student Assessment (PISA) 2012 has put Malaysia in the bottom third as about 50 percent of students aged 15 years old are unable to achieve the minimum level in the assessment. Therefore, one of the main focuses of the MoE is to improve overall student achievement and bridge the performance gap. At the same time, the ministry places emphasis on ensuring that every teacher and school leader achieves the quality standards set by the education authorities. Thus, the study is significant as it examines the practice of instructional leadership among school leaders, namely school headmasters in rural areas, and thus, the findings will be able to assist the MoE, Sabah Education Department and District Education Office to carry out their planning in order to improve the academic achievement at all levels, particularly in rural and remote areas, which are often associated with low socioeconomic issues.

\subsection{Conceptual Framework of the Study}

The conceptual framework (Figure 1) of this study is based on the Instructional Leadership Model developed by Hallinger and Murphy (1985). The independent variable used was the instructional leadership of the headmasters, which consisted of three dimensions, namely the dimensions of defining school goals, managing instructional programs, and promoting a positive learning climate. These dimensions are divided into 10 elements of instructional leadership, namely the practice of headmaster leadership in setting goals, disseminating those goals, supervising, and evaluating teachers' teaching, coordinating curriculum, monitoring student progress, controlling 
student progress, maintaining quality visibility in school programs, creating incentives for teachers, encouraging professional development, and providing incentives to students. This independent variable when manipulated will affect the dependent variable, for example school band achievement. The independent variable of the study refers to the instructional leadership practices by headmasters that will influence the performance of UPSR examination, and in turn will affect the dependent variable - school band achievement. The instructional leadership of headmasters could be manipulated by the mediating variable i.e. teachers will influence the academic achievement performance of students. Students' academic performance affects the GPA in the UPSR, and this will affect the value of the composite index score, which is a measure for determining the school band. The dimension defining school goals lists two subdimensions, namely formulating school goals and disseminating school goals. The dimension of managing an instructional program has three elements, namely supervising and evaluating teaching, coordinating the curriculum, and monitoring student progress. While the dimension of encouraging learning climate lists five subdimensions namely controlling teachers' teaching time, maintaining visibility, providing teacher incentives, encouraging professional development, and providing student learning incentives.

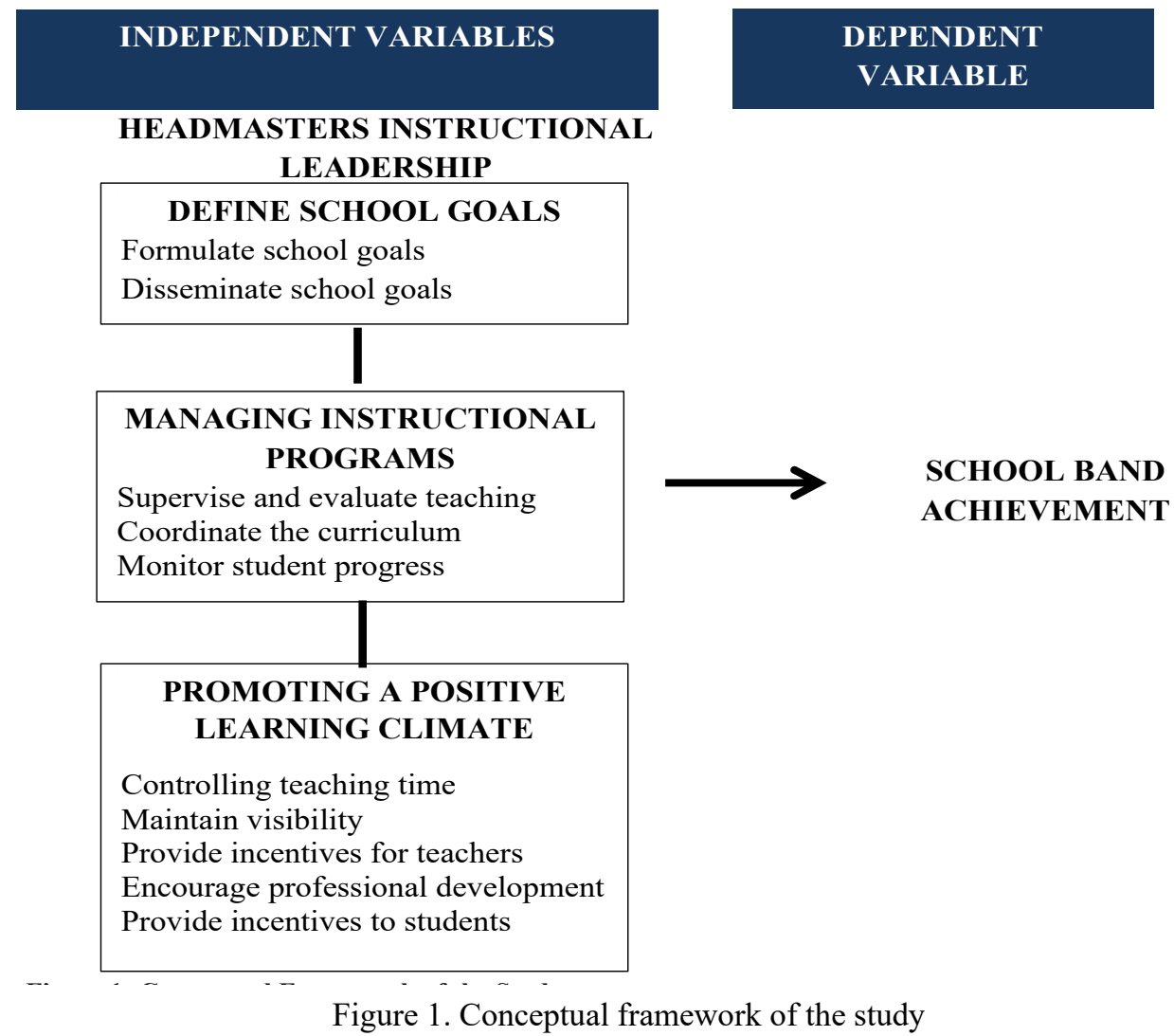

\section{Literature Review}

Hallinger (2000) refers to instructional leadership as the behavior of principals or headmasters who formally interact with teachers to enhance the credibility and capacity of teachers in the classroom. Pansiri (2008) refers to instructional leadership with the role of principal or headmaster, namely: (a) coordinating, controlling, supervising and developing curriculum and teaching, (b) interacting and communicating with teachers in order to improve the quality of teaching and learning, (c) as an instructional leader focused on the goal of improving student learning outcomes, (d) as an agent of change that creates a positive culture and climate as well as sets high expectations for teachers and students.

Various researchers have discussed and debated the importance of instructional leadership. For example, Blasé \& Blasé (2002) see instructional leadership in two main areas, namely as a teaching leader, communicating with teachers to enhance self - reflection and encourage the improvement of teachers' skills and professionalism. They also say that effective instructional leadership requires principals or headmasters to have effective communication by using a variety of methods to communicate with teachers. For example, teaching, giving guidance, suggestions, feedback, showing the way, sharing opinions, and giving appreciation to the achievements and excellence of teachers. 
Meanwhile, according to Azlin Norhaini (2006), principals or headmasters are faced with tasks and responsibilities that are too complex so that they seem less focused, creative, lost focus and problematic in terms of planning and implementation of activities provided to affect school excellence. Azian (2010) and Hussein (1993) also said that principals or headmasters can influence school achievement directly and indirectly. Therefore, there are schools that are still able to produce excellent results even if the principal or headmaster does not conduct teaching and learning in the classroom. Schools still excel because principals or headmasters can influence the quality of teaching and learning in the classroom through instructional leadership practices that include efforts to formulate school goals, communicate and define high achievement expectations, create conducive classrooms, allocate resources, supervise teacher performance, monitor progress pupils as well as the creation of a positive school climate and environment. The role of instructional leadership should not only revolve around traditional functions such as setting school goals, providing educational resources, managing curriculum, evaluating, monitoring teacher teaching and learning, but should be extended to the application of technology in teaching and learning, stimulating teacher professionalism and leveraging data in decision making in instructional leadership. Past studies have shown that the instructional leadership of principals is an important factor to the existence of effective schools, i.e. schools that produce high quality pupils (Hallinger, 2003). This statement is supported by Zakaria (2016) who state that instructional leadership is the main pulse in determining school effectiveness.

A study conducted by the Aminuddin Baki Institute (2002) on senior principals in Malaysia found that the principal can be a determinant of the progress or decline of a school. The findings conclude that school leaders should have high values and commitment have a clear vision and direction, have high skills in gathering information, supervision, evaluation and be able to make continuous improvement.

\section{Methodology}

Researchers used a questionnaire instrument developed by Hallinger (2000), the Principal Instructional Management Rating Scale (PIMRS), which divides principals' instructional leadership into three dimensions. These three dimensions consist of school goals, instructional program management and promoting a positive learning climate. The study respondents consisted of senior assistant teachers of administration, student affairs and co-curriculum. Of the 74 primary schools in Tuaran District, the researcher found that there are 222 senior assistant teachers. However, based on the formula of Krejcie and Morgan (1970), only 141 people were selected as the sample and respondents by using the determination of sample size at the significance level of $p<0.05$ and the sample was selected randomly for the purpose. The total number of questionnaires distributed to band 1 schools was 45 sets with 42 being returned, a total of 51 out of 57 forms were received from band 2 schools, band 3 schools $(90 ; 78)$ and band 4 schools $(30 ; 24)$. The method and process of obtaining samples is continued until the required respondents are sufficient (Azizi Yahaya et al., 2007).

The questionnaire instrument provided consists of three parts, namely Parts A, B and C with a total number of questions is 57 . To strengthen the research process, researchers have conducted a pilot study in primary schools in the district of Tamparuli involving 42 respondents, which is 30 percent of the actual study sample. For the ethical criteria of the study, the researchers had obtained the permission of the District Education Department and the Headmaster of the school before distributing the questionnaire form, which was collected back after one week, thus giving sufficient time for the respondents to answer. For data triangulation, the researcher also obtained information by examining reports, magazines and school records that can be obtained at schools and District Education Offices. In this study, the researcher used Statistics Package for Social Science 21.0 software to analyze the data. Descriptive analysis in terms of percentage, mean and standard deviation was used to decipher demographic information. In addition, ANOVA and Pearson Correlation tests were also used. To obtain data on students' academic performance, researchers obtained data by analyzing school achievement in the UPSR examination. For that purpose, the results of three years namely 2014, 2015 and 2016 were also analyzed.

\section{Findings}

Of the 141 respondents who participated in this study, 87 people or 61.7 percent were male while the remaining 38.3 percent were female. Respondents were in high grades indicating that the senior assistant teachers were senior and experienced teachers. Therefore, this group of respondents is seen to have a high capacity to provide an assessment of the leadership practices of headmasters in their respective schools. In terms of age, 21 people or 14.9 percent of respondents were aged 40 years and below, $41-50$ years (56 percent), 51-59 years (29.1 percent); directly shows that 85.1 percent of the respondents are those aged 40 years and above, which is a group of respondents who are quite experienced with a long period of service in the education sector. Therefore, in terms of demographics of respondents according to positions held, the researcher has selected respondents from among 
senior assistant teachers of curriculum and administration, student affairs and co-curriculum in a balanced manner, respectively 33.3 percent for each level of position. Therefore, this study has met a balanced sampling in terms of positions held.

\subsection{Objective 1: Levels of Instructional Leadership Practices by Headmasters}

It was found that the mean score of the level of instructional leadership practice among headmasters was high, namely 4.24 with a standard deviation of 0.398 . Leadership practice in dimension 1 (defining school goals), which involved two elements of instructional leadership, namely formulating school goals and disseminating school information, was the highest practiced, having a mean of 4.44 with a standard deviation of 0.61 . Meanwhile, dimension 2 (managing teaching programs) and dimension 3 (promoting a positive learning climate) had a mean of 4.22 and 4.18 , respectively, with standard deviations of 0.67 and 0.71 . This practice is at a high level, indicating that headmasters place high emphasis on the dimension of managing instructional programs and the dimension of promoting a learning climate in instructional leadership in schools.

Analysis also shows that there are elements that have high mean, indicating given high emphasis in instructional leadership. Among the popular instructional leadership elements are fostering the development of professionalism with the highest mean of 4.44 and standard deviation of 0.586 , followed by the element of formulating school goals with a mean of 4.42 and standard deviation of 0.589 , and the element of communicating with school goals with a mean of 4.40 and standard deviation of 0.631 (Table 1). Meanwhile, the findings of the study also show that there are elements that have moderate mean, which shows that it is given less emphasis by headmasters. Among the three less popular elements of instructional leadership are providing incentives for teachers, with a mean of 3.91 and standard deviation of 0.816 , protecting instructional time (mean 4.0 and standard deviation 0.735 ) and maintaining visibility in all school programs (mean 4.08 with standard deviation of 0.744 ).

Table 1. Level of mean based on instructional leadership elements

\begin{tabular}{llll}
\hline Elements of Instructional Leadership & Mean & Standard deviation & Interpretation \\
\hline Fostering the Development of Professionalism & 4.44 & 0.586 & High \\
Formulate School Goals & 4.42 & 0.589 & High \\
Communication With School Goals & 4.40 & 0.631 & High \\
Coordinating Curriculum & 4.27 & 0.646 & High \\
Providing Learning Incentives & 4.22 & 0.661 & High \\
Teaching Supervision and Evaluation & 4.16 & 0.658 & High \\
Monitor Students' Progress & 4.15 & 0.695 & High \\
Maintaining Visibility & 4.04 & 0.744 & High \\
Protecting Instructional Period & 4.0 & 0.735 & High \\
Providing Incentives for Teachers & 3.91 & 0.816 & Moderate \\
\hline
\end{tabular}

4.1.1 Analysis and Items of Instructional Leadership Dimension

In this section, the analysis of principals 'instructional leadership is discussed based on dimensions, namely (i) the dimension of defining school goals, (ii) managing instructional programs, and (iii) promoting a positive learning climate. Data analysis showed that the dimension defining school goals had the highest mean, namely 4.44 with a standard deviation of 0.61 . This indicates that the headmaster gives high priority to the aspect of preparing and disseminating the vision and mission of the school in his instructional leadership. Mean scores and standard deviations to all items in the dimension defining school goals showed high values - exceeding 4.0.

\subsubsection{Managing Instructional Programs Dimension}

The classroom teaching and learning process is a major task and is directly related to instructional leadership. The management of instructional programs is closely related to the process of supervision, evaluation, coordination, and monitoring of student progress. The findings of the study showed that the mean score and standard deviation for the level of instructional leadership practice of the dimension of managing instructional programs were high, with a mean of 4.22 with a standard deviation of 0.67 . The instructional leadership element with the highest mean was 'curriculum alignment', which was 4.30 with a standard deviation of 0.646 . The item with the lowest mean is item B24, which is to inform the teacher in writing about the school's performance. This item has a mean of 3.91 with a standard deviation of 0.751 , where the implementation is at a moderate level. This means that respondents see the headmaster's emphasis on these aspects in his instructional leadership as 'sometimes' only. 


\subsubsection{Promoting a Learning Climate Dimension}

Promoting a learning climate in schools is one of the dimensions of instructional leadership, which is divided into five main elements, namely controlling teachers' teaching time, promoting professional development, ensuring constant visibility in schools, emphasizing academic excellence, creating incentives for teachers, and creating incentives for students. The findings of the study showed that the dimension of 'promoting a learning climate' had a mean of 4.18 with a standard deviation of 0.71 . Although the mean score of this dimension showed a high level of practice, but the item analysis showed that the eight items of this dimension were in the moderate mean level, meaning that these aspects were given less emphasis by the headmasters. In fact, the analysis also showed that there were three items with the lowest mean, namely item B39 (special reward for teachers' efforts to improve professional development), item B28 (ensuring that students who skip school continue to be given guidance so that no one is left behind) and item B38 (recognizing teachers' outstanding performance by writing appreciation memos to be included in their personal files) with mean of 3.61, 3.72 and 3.79 respectively.

\subsection{Objective 2: Level of Instructional Leadership of Headmasters Based on School Bands}

The second research question in the study was to identify the level of instructional leadership based on the school band. The primary school band achievement record in Tuaran District in 2015 showed that 15 schools were in Band 1, 19 (Band 2), 30 (Band 3) and 10 (Band 4). This means that 10 or 20.27 per cent are high performing schools while 49 schools or 66.22 per cent are medium performing and the remaining $13.51 \%$ are low performing schools. The results showed that Band 1 schools had a high mean level of instructional leadership practice compared to Band 2, 3 and 4 schools which was 4.37 with a standard deviation of 0.254 (Table 2). Band 2, 3 and 4 schools each had a mean level of instructional leadership practice which was a mean of 4.23 with a standard deviation of $0.271,4.23$ with a standard deviation of 0.229 and 4.05 with a standard deviation of 0.298 . It shows the level of instructional leadership of headmasters based on district school bands is high, meaning the headmaster has performed his duties and role as an instructional leader with a high level of practice. In the meantime, data analysis based on the dimensions of instructional leadership, it was found that there are differences in instructional leadership practices according to school bands. Band 1 schools had a higher mean level of practice compared to schools in other bands (Table 3).

Table 2. Overall Outcome of Mean Based on School's Band

\begin{tabular}{llll}
\hline Schools' Band & Mean & Standard deviation & Level \\
\hline Band 1 & 4.37 & 0.254 & High \\
Band 2 & 4.23 & 0.271 & High \\
Band 3 & 4.23 & 0.229 & High \\
Band 4 & 4.05 & 0.298 & High \\
\hline
\end{tabular}

Table 3. Outcome of Mean Based on Scools' Band and Respective Dimensions

\begin{tabular}{llll}
\hline Schools & Dimension & Mean & Level \\
\hline \multirow{3}{*}{ BAND 1 } & D1: Defining the Goals of the School & 4.60 & High \\
& D2: Managing Instructional Programs & 4.38 & High \\
& D3: Promoting Positive Learning Climate & 4.29 & High \\
\hline \multirow{3}{*}{ BAND 2} & D1: Defining the Goals of the School & 4.46 & High \\
& D2: Managing Instructional Programs & 4.16 & High \\
& D3: Promoting Positive Learning Climate & 4.18 & High \\
\hline \multirow{3}{*}{ BAND 3} & D1: Defining the Goals of the School & 4.42 & High \\
& D2: Managing Instructional Programs & 4.23 & High \\
& D3: Promoting Positive Learning Climate & 4.16 & High \\
\hline \multirow{3}{*}{ BAND 4} & D1: Defining the Goals of the School & 4.23 & High \\
& D2: Managing Instructional Programs & 4.07 & High \\
& D3: Promoting Positive Learning Climate & 3.96 & Moderate
\end{tabular}

D = Dimension; D1 = Defining the Goals of the School; D2 = Managing Instructional Programs; D3 = Promoting a Positive Learning Climate 


\subsection{Objective 3: The Level of Instructional Leadership Practices Based on Demographic Factors}

Statistical analysis of ANOVA showed that the gender aspect had a significant value of $0.825(\mathrm{~F}=0.793: \mathrm{p}=$ $0.825>0.05$ ). Since the significant value was greater than $p=0.05$, it was decided that there was no significant difference in terms of the level of instructional leadership practice of headmasters based on gender factors (Table 4). In terms of age, it was found that the significant value was $0.319(\mathrm{~F}=1.117: \mathrm{p}=0.319>0.05)$, which was greater than $p=0.05$, and thus showed no significant difference in the level of instructional leadership practice. This means that the respondents' perceptions of the instructional leadership of headmasters based on the demographics of gender, age, grade, position held and the level of education of the respondents were not without significant differences.

Table 4. One-Way ANOVA Analysis on the Aspects of Headmasters' Instructional Leadership Practices Based on Demographics Factors

\begin{tabular}{lllllll}
\hline \multirow{3}{*}{ Gender } & & Sum of Squares & $\mathrm{df}$ & Mean Square & F & Sig. \\
& Between Groups & 11.969 & 58 & .206 & .793 & .825 \\
& Within Groups & 21.350 & 82 & .260 & & \\
Age & Total & 33.319 & 140 & & & \\
\hline \multirow{3}{*}{ Grade } & Between Groups & 26.113 & 58 & .450 & 1.117 & .319 \\
& Within Groups & 33.050 & 82 & .403 & & \\
& Total & 59.163 & 140 & & & \\
\hline \multirow{3}{*}{ Position held } & Between Groups & 40.284 & 58 & .695 & .977 & .532 \\
& Within Groups & 58.283 & 82 & .711 & & \\
& Total & 98.567 & 140 & & & \\
\hline \multirow{3}{*}{ Education level } & Between Groups & 40.733 & 58 & .702 & 1.081 & .369 \\
& Within Groups & 53.267 & 82 & .650 & & \\
& Total & 94.000 & 140 & & & \\
\hline & Between Groups & 11.746 & 58 & .203 & .529 & .994 \\
& Total & 43.163 & 140 & & & \\
\hline
\end{tabular}

At the confidence level of $95 \%, \mathrm{p}=0.05$

\subsection{Objective 4: The Relationship of Headmaster Instructional Leadership Practice with Band Achievement}

In the meantime, Pearson Correlation analysis was conducted to look at the relationship of instructional leadership with school band achievement. Test results showed that there was a weak negative correlation between the level of instructional leadership of headmasters with school band achievement $\left(r=0.210^{*}, p<0.05\right)$ (Table 5). This proves that the level of instructional leadership practice of headmasters has a weak negative relationship with school band achievement. In other words, an increase or decrease in the level of instructional leadership practice will have a weak negative impact on the performance of the school band. For example, an increase in a Band 3 to Band 1 school may occur due to other factors. For example, environmental factors, socioeconomics of parents and increase in composite scores in Malaysian Education Quality Standards (SKPM) are not necessarily factored by the increase in the level of instructional leadership practices of headmasters.

Table 5. Correlation Analysis of Instructional Leadership and Its Relationship with Schools' Band Achievement

\begin{tabular}{llll}
\hline & & Instructional leadership & School's band achievements \\
\hline Instructional leadership & Pearson Correlation & 1 & $-.210^{*}$ \\
& Sig. (2-tailed) & $\cdot$ & .013 \\
& $\mathrm{~N}$ & 141 & 141 \\
School's band achievements & Pearson Correlation & $-.210^{*}$ & 1 \\
& Sig. (2-tailed) & .013 &. \\
& $\mathrm{~N}$ & 144 & 141 \\
\hline
\end{tabular}

*. Correlation is significant at the 0.05 level (2-tailed) 


\section{Discussions}

\subsection{Levels of Headmasters' Instructional Leadership Practice}

It is found that the level of instructional leadership practices among headmasters in Tuaran District is at a high level with a mean of 4.24 and a standard deviation of 0.398 . Dimension-based analysis showed that leadership practices in dimension one, which involved two elements of instructional leadership, namely formulating school goals and disseminating school information had a mean of 4.44 while dimension two (instructional program management) had a mean of 4.23 and dimension three (promoting a learning climate) received a mean of 4.18. Thus, it can be concluded that headmasters practice high levels of instructional leadership. Analysis based on instructional leadership elements shows that there are elements that have a high level of mean and some that are low. The outcome suggests that some of these elements are given emphasis in instructional leadership, and some are given less priority. For example, fostering the development of professionalism is the element that has the highest mean of 4.44, followed by the element of formulating school goals (mean 4.42). The third highest was the element of communicating with schools' goals which had a mean of 4.40. The aspect that had a moderate level mean, which showed less emphasis, was the element of providing incentives for teachers, where the mean obtained was only 3.91 .

\subsection{Level of Instructional Leadership Practices from the Perspective of Defining Schools' Goals Dimension}

The instructional leadership practices among headmasters in-term of defining schools' goals dimension had recorded a mean of 4.44. Analysis of scores and standard deviations also showed that the level of instructional leadership practices for the dimension of defining schools' goals on each item was high, exceeding 4.0. This clearly explains that leadership practices for this dimension is at a high level. The two elements of instructional leadership in this dimension, i.e., formulating school goals and disseminating schools' goals have a high mean of 4.42 and a standard deviation of 0.589 , and 4.40 with a standard deviation of 0.631 , respectively. On the other hand, it was found that three items - B4 (using students performance data in developing school academic goals), B7 (discussing academic goals with teachers during school meetings) and item B6 (communicating effectively with school community members with respect to the goals of school) are being practiced 'almost always' by headmasters, and had a mean of 4.53, 4.50 and 4.47, respectively. This indicates that instructional leadership ensures that the schools have a clear direction and is understood by all members of the school community. The finding is in line with points asserted by many researchers such as Hallinger and Murphy (1985), Weber (1996) and Hussein (1993).

\subsection{Level of Instructional Leadership Practices from the Perspective of Managing Instructional Programs Dimension}

The findings show that the mean for instructional leadership practices in-term of managing instructional programs dimension is 4.22 - is high. The item with the highest mean was B16 (clearly defining the distribution of tasks for curriculum coordinators according to level/degree has a mean of 4.53 with a standard deviation of 0.633, and indicating 'almost always' being practiced by headmasters, while item B24 (informing teachers in writing about school performance) had the lowest mean of 3.91 with a standard deviation of 0.751 . These findings directly indicate that instructional leadership practices among head teachers emphasize clear justification in informing the distribution of curriculum tasks to teachers.

5.4 Level of Instructional Leadership Practices from the Perspective of Encouraging the Learning Climate Dimension

The level of instructional leadership of the dimension promotes a learning climate has a mean of 4.17, and this shows that it is being practiced 'almost always' by headmasters. A popular item implemented by headmasters is item B50, which fully supports the efforts of teachers in giving appreciation or gifts to students for contributions or achievements in class with a mean of 4.55 and a standard deviation of 0.591 . Meanwhile, the item that has the lowest mean and is practiced 'frequently' by headmasters is item B28, which is a special reward for teachers' efforts to improve development with a mean of 3.61 and a standard deviation of 0.962 . The low-level instructional leadership practices need to be enhanced as emphasized in Halliger \& Murphy's (1985) Instructional Leadership Model, Weber's (1996) Instructional Leadership Model and Hussein's (2008) Leadership Model which assert that the implementation of instructional leadership by headmasters is a key determinant to schools' achievement.

\subsection{Headmasters Instructional Leadership Level Based on School Band or Performance Levels}

Analysis shows that there are clear differences in the instructional leadership practices among Band 1 and Band 4 schools. The level of instructional leadership practices among Band 1 school headmasters had recorded a mean 
of 4.40, while the mean level in Band 4 schools was 4.05. Band 2 and 3 schools have the same mean level -4.22 . Overall, the mean level is considered high, and shows that headmasters of Band 1, 2, 3 and 4 schools have high level of instructional leadership practices. Data analysis based on the instructional leadership dimension showed that Band 1 schools have a higher mean in all dimensions compared to other schools. For example, the mean level for dimension such as define school goals, Band 1 schools have a mean of 4.58 while Band 4 schools' mean around 4.23. Similarly for the the dimension of managing instructional programs, the mean level for Band 1 schools is about 4.37 and Band 4 schools recorded 4.07. Even in the dimension of promoting positive learning climate, the mean level for Band 1 schools is 4.28 while Band 4 schools is only 3.96. The outcomes show that in reality the practice of instructional leadership in Band 1 schools is higher compared to low-performing schools. Based on descriptive statistical analysis, it was found that the most dominant dimension of instructional leadership practiced among headmasters in Tuaran is the dimension of define school goals with a mean of 4.41.

The second most dimension is, managing instructional programs with a mean of 4.19 , and third, the dimension promoting positive learning climate with a mean of 4.12. In-term of items that were analysed, the instructional leadership item with the highest mean is item B4 (using students' performance data to develop schools' academic goals) -4.35 . The second is item B50 (fully supporting efforts of teachers in giving appreciation or gifts to students for their contributions or achievements in the class) - 4.51. Third, items such as B7 (discussing academic goals with teachers during school meetings), B16 (clearly defining the distribution of tasks for curriculum coordinators according to level of education/degree) and B43 (ensuring the participation of all staff in internal courses) have same level of mean -4.50 . The outcome for all items considered high and indicates that the headmasters are adopting an 'almost always' style in-term of leadership practices and is in line with the need to improve students' performance. The finding is similar with the outcome of Jamelaa's (2012) study, which defined that headmasters' emphasis on the instructional leadership dimension will have a positive impact on achievement level among students.

\subsection{Headmasters' Instructional Leadership Practices Based on Demographic Factors}

Differences in the level of instructional leadership practices among headmasters based on demographic factors of respondents were analyzed using ANOVA test. Thus, the findings show that gender, age, position held and grade, and level of education have no significant differences on the instructional leadership. The gender aspect had a significant value of 0.825 , age (0.319), grade (0.532) and position held (0.369) as well as education level showed a significant value of 0.994 . Since the significant value was greater than $p=0.05$, the study concludes that there are no significant differences in the level of instructional leadership practices among headmasters based on the demographic factors of the respondents.

\subsection{Headmasters' Instructional Leadership Practices and Its Relationship with Achievement of Schools}

Pearson Correlation analysis showed that there was a weak negative correlation between the instructional leadership of headmasters with schools' achievement level or band of schools $\left(r=-0.210^{*}, p<0.05\right)$. This explains that an increase or decrease in the level of instructional leadership practices will not necessarily affect the performance of the school's band level. For example, the increase in school band achievement for example from Band 2 to Band 1, is not necessarily the result of an increase in the level of instructional leadership practice and vice versa. These findings are in line with the findings of a study by Usang (2012), in secondary schools in Sarawak, whose findings show that there is a weak negative relationship between principals' teaching leadership and student performance in examinations.

\section{Implications and Recommendations}

The researcher concluded that the instructional leadership practices among primary school headmasters in Tuaran District, Sabah is quite high. They have performed their duties as instructional leaders in line with the aspirations of the MoE outlined in the PPPM, which places high-performing leaders for the interest of educational excellence. Second, the dimension of defining schools' goals has the highest score, thus shows that it is given high priority by many headmasters. The dimension of managing teaching programs and promoting a positive learning climate are in the second and third position respectively in terms of priority. Third, the study found that headmasters in Band 1 schools have higher level of instructional leadership practices compared to Band 2 and 3 schools. There are many factors that influence the excellence of each school. The leadership factor is just one of them. Demographic, geographical, socio-economic status of parents and the local environment also influence schools' excellence. Overall, it was found that the instructional leadership practices by headmasters should emphasize all three dimensions of instructional leadership that have been discussed, namely defining the goals of their respective schools, managing instructional programs, and promoting a positive learning climate. The finding is in line with Zakaria's (2016) study that was conducted to examine the under-enrolled schools in 
Malaysia, which found that headmasters practice high instructional leadership in the development of their school's mission and vision.

\section{Conclusion}

The researcher successfully identified the level of instructional leadership practices among headmasters of primary schools in Tuaran District, Sabah. In fact, the researcher also identified differences in the level of instructional leadership practices based on the level performance of schools or band. Since school performance is determined based on band, it is clear that high level of instructional leadership practices exist in high-performing schools, and vice versa. The most popular dimension of instructional leadership practiced by headmasters is defining the mission of the school and followed by the dimension of managing instructional programs and finally, the dimension of promoting a positive learning climate. Indeed, an important dimension in effective instructional leadership of headmaster is the ability to prepare or formulate the vision and mission of their schools, then spread widely to the entire school community and in turn, it will support and create a climate of shared goals. Since the effectiveness of schools in terms of academic achievement depends on the quality of teaching and learning in the classroom, the focus on two important aspects, namely maximizing teaching time and emphasis on academics should be the focus of the schools' leadership.

\section{Acknowledgement}

This paper is supported by Universiti Kebangsaan Malaysia research grant (Code: GUP-2021-062).

\section{References}

Aminuddin Baki Institute. (2002). Traces of excellence in school management: A collection of records of the success of Malaysian senior principals in developing schools. Kuala Lumpur: Rita Business.

Azian Ahmad Shaharbi. (2010). Leadership Behaviour and Practices of a Head Teacher in an Excellent School. Unpublished Master Thesis. Open University Malaysia.

Azizi Yahaya, Sharhrin Hashim, Jamaludin Ramli, Yusof Boon, \& Abdul Rahim Hamdan. (2007). Mastering research in education: Theory of data analysis and interpretation. Kuala Lumpur: PTS Profesional Publishing sdn.Bhd.

Azlin Norhaini Mansor. (2008). The Management role of school principals. Journal of Research, 10, 119-136. Retrieved from https://www.jossr.com/PDF/JOSSR-2019-03-06-01.pdf

Blasé, J., \& Blasé, J. (2002). Teachers' perception of principals' instructional leadership and implications. Leadership and Policy in Schools, 1(3), 256-264. https://doi.org/10.1076/lpos.1.3.256.7892

Hallinger, P., \& Murphy, J. (1985). Assessing the instructional management behaviors of principals. The Elementary School Journal, 86(2), 217-247. https://doi.org/10.1086/461445

Hallinger, P. (2000). A review of two decades of research on the principalship using the Principal Instructional Management Rating Scale. Paper presented at the annual meeting of the American Education Research Association, Seattle, WA.

Hallinger, P. (2011). Leadership for learning: lessons from 40 years of empirical research. Journal of Educational Administration, 49(2), 125-142. https://doi.org/10.1108/09578231111116699

Hussein Mahmood. (2008). School effectiveness leadership (2nd ed.). Kuala Lumpur: Dewan Bahasa dan Pustaka.

Jamelaa Bibi Abdullah. (2012). Instructional leadership practices and attitudes towards change among secondary school principals in Pahang state. PhD Dissertation. National University of Malaysia.

James Ang Jit Eng, \& Balasandran Ramiah. (2011). Instructional leadership: A practical guide. PTS Professional Publishing.

Mohd. Suhaimi Mohamed Ali. (2004). Instructional leadership practices of rural secondary school principlas. Thesis Doctor of Philosophy. University Putra Malaysia.

Mohd. Yusuff Mohd Nor, \& Sufean Hussin. (2013). Educational democracy: The dilemma of small and centralised schools. Kuala Lumpur: University of Malaya Publishers.

Pansiri, N. (2008). Instructional leadership for quality earning: Primary school management development project in Botswana. Educational Management Administration \& Leadership, 36(4), 471-494. https://doi.org/10.1177/1741143208095789 
Rutil Taising, \& Gunasegaran Karuppannan. (2020). Principals' management empowerment practices and its relationships with work satisfaction among school mid-level administrators. Selangor Humaniora Review, 4(2). Retrieved from https://share.journals.unisel.edu.my/ojs/index.php/share/article/view/117

Sazali Yusoff, Rusmini Ku Ahmad, Abang Hut Abang Engkeh, \& Zamri Abu Bakar. (2007). The relationship between instructional leadership to effective schools. IAB Management Journal, 107-119.

Sufean Hussin. (2014). Instructional leadership and school culture of high-and low-performing school: Patterns of variation relationship. IOSR Journey of Humanities and Social Science, 19(3). https://doi.org/10.9790/0837-1934138144

Usang Anak Ngrambang. (2013). Implications of principals' teaching leadership and teachers' job satisfaction on examination performance in rural secondary schools in Sarawak. Research Journal, 5.

Weber, J. (1996). Leading the instructional program. In Smith, S. \& Piele, P. (Eds.), School Leadership. Handbook for Excellence in Student Learning (4th ed.). California: Corwin Press.

Zakaria Othman. (2016). Instructional leadership of principals in underserved schools. Doctor of Philosophy Thesis. University of Malaya.

\section{Copyrights}

Copyright for this article is retained by the author(s), with first publication rights granted to the journal.

This is an open-access article distributed under the terms and conditions of the Creative Commons Attribution license (http://creativecommons.org/licenses/by/4.0/). 